\title{
The Relationship between Long-Term Incentives and Corporate Performance: A Theoretical Review
}

\author{
*Robert Oguti Etengu \\ Jomo Kenyatta University of Agriculture and Technology (JKUAT) \\ College of Human Resource Development P.O BOX 62000-00200 \\ City Square, Nairobi, Kenya \\ retengu@yahoo.com \\ Adam Kwerigira \\ Islamic University in Uganda (IUIU), P.O BOX 2555, Mbale, Uganda \\ adamkwe@gmail.com
}

\begin{abstract}
The study empirically reviewed literature on the relationship between long-term incentives and corporate performance. More specifically, the study reviewed literature on the relationship between long-term incentives and market performance, and the relationship between long-term incentives and accounting performance. The findings of the study revealed a significant positive relationship between long-term incentives and market performance. For the few studies that focused on the relationship between long-term incentives and accounting performance, the findings were that the adoption of long-term incentive plans isn't related to contemporaneous accounting performance.
\end{abstract}

Keywords: Long-term incentives, market performance, accounting performance, corporate performance

\section{INTRODUCTION}

Over the past two decades, academic literature on agency theory and executive compensation has argued that executive compensation should be aligned to firm performance (Cooper, Gullen, Rao, 2009). Of late, politicians and the media have argued that current executive compensation practices push employees to take short-term risks with little regard for the long-term effect on their companies. Consequently, there has been a regulatory proposal that more pay be offered through restricted stock or other forms of long-term compensation designed not to reward short-term performance.

This study empirically reviews literature on the relationship between long-term incentives (LTIs) and corporate performance. More specifically, the study aims to achieve the following objectives:

- To empirically review literature on the relationship between LTIs and market performance.

- To empirically review literature on the relationship between LTIs and accounting performance.

The justification for this choice is that studies that address this link have focused on connections between pay and future accounting performance (see for example Hayes \& Schaefer, 2000; Bolton, Scheinkman, \& Xiong, 2002; Bryson, Freeman, Lucifora, Pellizzari, \& Perotin 2012; Cready, Dai, \& Mai, 2012; Nyberg, Pieper, \& Trevor, 2014). Therefore the link between long-term incentive pay and corporate performance has not received much attention more so in emerging markets in Africa.

According to Stabile (1999) the focus on the use of various forms of LTIs as a means of motivating executives reflects a concern with addressing the agency costs created by the separation of ownership and management inherent in the corporate form of organisation. It attempts to minimise agency costs by making it financially advantageous for executives to behave in a way that serves the interests of owners.

The paper is organised as follows: the second section presents the literature review, and the third section concludes on the way forward in as far as the relationship between LTIs and corporate performance is concerned. 


\section{LITERATURE REVIEW}

In this section we present a review of literature on executive compensation, the relevant theories that attempt to explain executive compensation, corporate performance as a determinant of executive compensation, the relationship between executive compensation and corporate performance, the relationship between LTIs and corporate performance, the relationship between LTIs and accounting performance, and a summary and critique of the literature reviewed.

\subsection{Conceptualisation of Executive Compensation}

Conceptually executive compensation refers to all forms of financial returns and tangible services and benefits that employees receive as part of an employment relationship (Greckhamer, 2011). CEO compensation typically consists of three components: a basic salary, an annual cash bonus plan (shortterm incentive), and a stock-based plan (LTIs).

According to Mnzava (2012) basic salary is the key component of executive compensation that guarantees a minimum increase over time. Contrary to other components of executive compensation, basic salary is a fixed component in executive contracts and can be reviewed on an annual basis. The same author (Ibid, 2012) puts it that most profit-making companies offer bonus schemes to their top executives that are paid annually, depending on the overall performance of the respective company.

The stock-based plans are defined as being portions of a company's stocks that are not fully transferable until certain conditions have been met (Neslihan, 2007). They include stock options, performance-based incentives and restricted stock. The most prevalent form of long-term compensation is the stock option which grants the holder of the option the right (but not the obligation) to purchase a specified number of shares of company stock at a price that is fixed at the date of grant (Stabile, 1999).

Performance-based incentives typically take the form of performance shares. Biagi, Boner, Peek, and Burek (2015) inform that the use of performance-based LTIs continues to be the prevailing practice, constituting more than $50 \%$ of the typical LTI program for Named Executive Officers (NEO). The same authors (Ibid, 2015) argue that a shift towards performance-based LTI compensation reflects an effort by companies to respond to shareholder feedback and align executives' pay with performance as opposed to the use of stock options and time-based restricted stock.

Lastly but not least, restricted stock - one of the newest compensation methods - is stock that cannot be sold for some specified period of time. They are granted upon the attainment of a certain vesting period. Typically the goal is to provide an incentive for the executive to stay with the firm.

\subsection{Theoretical Review}

Although research on executive compensation continues to proliferate, there remains a lack of interdisciplinary consensus regarding the primary forces shaping observable patterns of executive compensation (Frans, 2014). The lack of consensus is most visible between scholars in economics and finance, who advocate for the primacy of market-based explanations, and scholars outside of these two disciplines, who have challenged these explanations, by highlighting the importance of the power of socio-psychological processes and the institutional environment in the creation of compensation practices.

In this section therefore we highlight the different theoretical perspectives in the field of economics and finance, and those embedded in the socio-cultural and political contextual settings that attempt to explain executive compensation. These include the equity theory, the principal agency theory, the structural theory, and the contingency theory.

\subsubsection{Equity Theory}

Boivie, Bednar, and Barker (2012) posit that what is most desirable about equity theory in terms of explaining executive compensation is that equity theory has been applied at both the individual and team levels of analysis. Equity theory offers predictions about how individuals react to over-reward and under-reward situations. Gomez-Mejia, Makri, and Larraza (2010) confirm that equity theory has played a predominant role in traditional compensation theory and practice.

According to equity theory, individuals make subjective assessments of the ratio of their inputs (effort) and outcomes (compensation) to those of referent others, and experience dissonance when 
their perceived ratio is unequal to that of others. Gerakos, Ittner, and Moers (2012) assert that employees seek to maintain equity between the inputs they provide and the outputs they receive in comparison to the perceived inputs and outputs of others.

\subsubsection{The Principal Agency Theory}

Hass, Liu, Young, and Zhang (2014) contend that mainstream academic research on executive compensation has its roots in agency theory. According to this theory, the agents (managers) and principals (owners) have different preferences concerning risks and effort, and this may result in manager decisions that are not optimal for the owners of the company.

Sun, Zhao, and Yang (2010) identify two streams of agency research: a normative principal-agent literature that seeks to design optimal compensation contracts with efficient risk bearing and a positive agency literature focused on the separation of corporate ownership and control. The former emphasizes the design of optimal contracts balancing the trade-off between the cost of evaluating behaviour and the cost of bearing risk, and in some cases the trade-off between incentives and monitoring. The latter focuses on the governance mechanisms that minimise agency problems, including managerial stock ownership aligning the interests of managers and shareholders, outcomebased incentive contracts that decrease managerial opportunism, a greater proportion of nonmanagement directors on the board effectively monitoring management, and concentrated ownership resulting in the active monitoring of management (Sun et al., 2010).

In order to reduce the agency costs organisations can use incentive schemes for managers in a bid to reward them financially for shareholder interests. Such schemes typically include plans whereby senior executives obtain shares, perhaps at a reduced price, thus aligning financial interests of executives with those of shareholders.

\subsubsection{The Structural Theory}

According to Maloa (2014), defenders of executive compensation have argued that executive compensation is a direct function of the number of organisational levels below executives, that is, other things being equal, the taller the organisational structure, the greater the earnings of top executives.

Gomez-Mejia et al. (2010) further contend that differences between ranks are not determined by economic forces, but rather through cultural processes that create relevant norms of social stratification. In a manner somewhat akin to traditional economic models, the structural perspective is very deterministic, with the earnings of executives being mechanically established as a function of the number of levels below them and a fixed percentage difference between their pay and that of their subordinates. The resulting pay scale thus complies with cultural norms of proportionality between the earnings of superiors and those of subordinates.

\subsubsection{The Contingency Theory}

Contingency theory is closely related to structural theory. However, while the focus of structural theory is internal, contingency theory considers external elements such as the environment in which an organisation operates (Hass et al., 2014).

According Hrebiniak and Joyce (1985) contingency theory asserts that managerial decisions are the result of adapting to environmental forces. Trevor (2011) further adds that the outcomes of the pay determination process are contingent upon the context in which pay determination occurs, which has implications for the pay outcomes experienced as a result. The same author (Ibid, 2011) notes that it is the markets and not managers that choose the prevailing strategies within a particular environment. Thus, paying attention to the various political and social pressures confronting people in organisations, both internally and externally, may facilitate more effective executive compensation decision-making.

Finkelstein and Boyd (1998) further argue that a determinant for improved firm performance is the result of a better match between CEO discretion and CEO pay. In particular, they contend that CEO pay should be higher in firms in which managers have greater discretion because they have more opportunity to positively or negatively impact firm performance. 


\subsection{Corporate Performance as a Determinant of Executive Compensation}

Of the various numerous determinants of executive compensation (board composition, ownership structure, and corporate size, among others); performance measures are the most frequently employed. The two common measures of corporate performance that are deployed in research are: the market performance-based, and the accounting performance-based metrics.

The most commonly used market performance-based measure is share price information (Hass et al., 2014). Other authors (like for example, Merhebi, Pattenden, \& Swan, 2006) argue that a common approach to measuring firm performance is to consider the change in shareholder wealth or stock price improvement, as it is shareholders' interests that are of primary concern to agency theorists. The accounting performance-based measures on the other hand include: return on equity (ROE), earnings before interest, tax, depreciation and amortisation (EBITDA), return on investments (ROI), return on assets (ROA), and economic value added (EVA), among other measures.

\subsection{The Relationship between Executive Compensation and Corporate Performance}

A number of studies have been carried out on the relationship between executive compensation and corporate performance in different contexts. However, it is not possible to bring out all these studies. This section therefore will only bring out the studies conducted by Agrawal, Makhija, and Mandelker (1991), Mcknight and Tomkins (1999), Boschen, Duru, Gordon, and Smith (2003), Kato and Long (2005), Bruce, Skovoroda, Fattorusso, and Buck (2007), Crumley (2008), Aduda (2011), Scholtz and Smit (2012), Kurawa and Saidu (2014), and Deysler and Kruger (2015).

Agrawal et al. (1991) carried out a study on executive compensation and corporate performance in electric and gas utilities in the U.S. The findings on public utilities were consistent with the view that compensation packages align the interests of most top managers with those of their stockholders. McKnight and Tomkins (1999) conducted a study on top executives' pay in the U.K. The findings of their study indicated that each component of executive compensation has its own determinants. For instance, salary per se was mainly determined by firm size rather than firm performance.

Boschen et al. (2003) carried out a study on accounting and stock price performance in dynamic CEO compensation in the U.S. The study found that good accounting performance is related with increases in CEO remuneration. However, this relationship reverses in later years where accounting performance is associated with lower CEO remuneration. On top of this, they found out that CEO's long-run cumulative remuneration is positive and statistically significantly related to stock price performance. Kato and Long (2005) conducted a study on executive compensation, firm performance, and corporate governance in China. The findings of the study were that there were statistically significant sensitivities and elasticities of annual cash compensation (salary and bonus) for top executives with respect to shareholder value in China. Besides, sales growth was shown to be significantly linked to executive compensation. Finally and more importantly, the study found that ownership structure of China's listed firms has important effects on pay-performance link in these firms.

Bruce et al. (2007) carried out a study on executive bonuses and firm performance in the U.K. by investigating executive bonuses for the period 2001 to 2003. Their main finding demonstrated that executive bonuses are related to higher total shareholder returns. Crumley (2008) examined the relationship between firm performance and CEO compensation in the U.S. commercial banking industry. The sample of his study covered 36 firms in the U.S commercial banking industry for the period 2002-2003. His results exhibited a weak relationship between CEO remuneration and firm performance.

Aduda (2011) conducted a study to examine the relationship between executive compensation and firm performance among the commercial banks listed on the Nairobi Stock Exchange (NSE). The findings of the study suggested that accounting measures of performance are not key considerations in determining executive compensation among the large commercial banks in Kenya and that size is a key criteria in determining executive compensation as it was significantly but negatively related to compensation. Scholt and Smit (2012) carried out a study on executive remuneration and company performance in South Africa. The study found that there was a strong relationship between executive remuneration and some company performance indicators, such as total assets, turnover and share price for companies listed on the AltX. 
Kurawa and Saidu (2014) carried out a study on executive compensation and financial performance of listed banks in Nigeria. The study found a positive and significant link between executive compensation and the profit before tax of the sampled banks. Their conclusion was that banks in Nigeria should consolidate and strengthen their top compensation structure with the use of incentive plans that guarantees both short (cash pay) and long (equity pay) terms for sustained financial performance. Lastly, Deysel and Kruger (2015) conducted a study on the relationship between South African CEO compensation and company performance in the banking industry. The overall findings of their study was that there was a statistically significant positive long-term correlation between the JSE Banking Sector market performance and CEO compensation, although not all banks included in the population exhibited this correlation.

\subsection{Empirical Review}

Summarising the massive literature on CEO pay to performance debate is not an easy task. In this section therefore we offer a brief summary of an empirical review of literature on the relationship between LTIs and market performance, and LTIs and accounting performance.

\subsubsection{The Relationship between LTIs and Market Performance}

One of the most extensively studied areas in line with executive compensation is the impact of incentives on stock market returns. The notable scholars in this regard include Masson (1971), Coughlan and Schmidt (1985), and Westphal and Zajac (1998).

Masson (1971) conducted a study on executive motivations, earnings and consequent equity performance in the U.S. His emphasis was on the analysis of financial incentives of executives theoretically and econometrically with particular emphasis on the relationship between executive motivations and sales maximisation. Data was obtained from a sample of top three to five executives of thirty nine electronics, aerospace, and chemical companies for the years 1947-66. The statistical aggregation technique used was the zero test which assesses the degree of confidence the investigator may have that a random sample of positive and negative numbers was not drawn from a distribution with equal probability of positive and negative numbers. The structures of individual firms' compensation packages were tested for effects on performance. The findings of his study were that firms that provided greater financial incentives for their CEOs exhibited better stock market performance over the post war period, which he interpreted as evidence that firms systematically provided sub-optimally low incentives.

Coughlan and Schmidt (1985) carried out a study on executive compensation, management turnover and firm performance. The hypotheses tested are that both compensation changes and management changes are methods used to control top management, and that the use of these control methods is motivated by changes in the firm's stock price performance. Public data from the period 1977-1980 were used to support their hypotheses. Their test sample was derived from the records of 249 corporations and contained 597 observations. The statistical methodology underlying their empirical tests was a logit regression in which the dependent variable is dichotomous, having a value of one when a CEO turnover occurs and a value of zero otherwise. The results of their study showed a statistically significant relationship between CEO compensation and stock price performance.

Westphal and Zajac (1998) carried out a study on the symbolic management of stockholders in the U.S. Their study specifically examined whether the stock market reacts favourably to specific governance mechanisms like the adoption of long-term incentive plans (LTIPs), whether providing agency related explanations for LTIPs affects the stock market response, and whether the symbolic adoption of LTIPs deters other governance reforms that would reduce CEOs' control over their boards. Data was analysed from 408 corporations over a ten-year period (1982 to 1992). They employed t-tests to ascertain if there was any significant relationship. The findings of their study were that: the stock market reacts positively to LTIP adoption whether or not the plans are actually implemented, and that using agency language results in a more favourable stock market reaction to LTIP adoption irrespective of whether the plans are implemented or not. With respect to internal consequences, the study also found that appeasing shareholders through the symbolic adoption of LTIPs substitutes for other changes in board structure that are thought to decrease CEO autonomy and increase the board's monitoring capacity. 


\subsubsection{The Relationship between LTIs and Accounting Performance}

Murphy (1985) conducted a study on corporate performance and managerial remuneration. $\mathrm{He}$ collected data on compensation and performance of 461 executives at 71 firms over a number of years. Murphy (1985) employed fixed-effects models and found that executive compensation is strongly positively related to corporate performance as measured by shareholder return and growth in firm sales.

Antle and Smith (1986) did an empirical investigation of relative performance evaluation of corporate executives. They used a very broad compensation measure that included cash compensation, stock and option grants and changes in value of executive holdings of stock and options. The data they used was the average pay of top executives at 36 firms in the chemical, aerospace, and electronics industries from 1947 to 1977 . The same authors (Ibid, 1986) constructed peer-group performance indices, weighted by the correlation between firm and peer ROA. Their study found a positive association between total management compensation and ROA as a performance measure.

Jensen and Murphy (1990) did a study on performance pay and top management incentives. The methodology they employed was the first difference method. Their estimates of the pay-performance relation (including pay, options, stockholdings, and dismissal) for CEOs indicated that CEO wealth changes $\$ 3.25$ for every $\$ 1,000$ change in shareholder wealth.

Fatemi, Desai, and Katz (2003) in their study examined the relationship between executive compensation and measures of firm performance that capture economic profits earned by the firm (EVA and MVA). They adopted a multivariate regression model in a bid to ascertain the correlation between firm performance and executive compensation. Their finding was that executive compensation is positively related to the level of risk borne by the firm and MVA is a significant determinant of executive compensation. At the same time the relationship between EVA and compensation was weak.

Firth, Fung, and Rui (2007) conducted a study to ascertain how ownership and corporate governance structure influence chief executive pay in China's listed firms. The focus of their study was on nonfinancial companies listed in Shanghai and Shenzhen Stock Exchanges between 1998 and 2000. They employed regression analysis to test the relation between pay, performance, ownership, and boardroom variables. The findings of their study indicated that ROA as a prime measure of performance is related to CEO remuneration.

Cao and O'Halloran (2012) carried out a study on CEO long-term incentive compensation plans and firm performance. They used a longitudinal sample of Irish publicly traded companies over a 6-year period from 2002 to 2007. Their study was a fixed effect study that reports mixed results. The findings of the study was that the adoption of LTIPs is not related to contemporaneous accounting and market performance.

\subsection{Summary and Critique}

This survey empirically reviewed literature on LTIs and corporate performance, and revealed the following pertinent issues. Firstly and foremost, there are many theories regarding executive compensation and not merely the popular principal agency theory. Specifically in this study, we reviewed literature on equity theory, structural theory, and contingency theory. Equity theory demonstrates that an individual will judge the level of his compensation in terms of whether or not it is fair when compared to the level of compensation of other executives performing the same job. Structural theory seeks to establish whether or not executive compensation is also informed by the job level that the executive occupies within the same organisation, and contingency theory suggests that the means by which organisations compensate their executives will be influenced by other external organisations. All these theories are complementary to one another and would better explain the performance-pay relationship.

Secondly, we observed that the relationship between executive compensation and corporate performance is obscured. Whereas some studies find that the relationship between executive compensation and corporate performance is weak (for example, Crumley, 2008; Aduda, 2011) other studies find a significant relationship between executive remuneration and corporate performance (for example, Boschen et al., 2003; Kato \& Long, 2005; Bruce et al., 2007; Deysel \& Kruger, 2015). Other studies like for instance, Mcknight and Tomkins (1999) find that each component of executive 
compensation has its own determinants for example salaries was determined by firm size. All these findings necessitate additional empirical investigation.

Thirdly and in as far as the relationship between LTIs and market performance is concerned, we established that most studies concentrated on the relationship between total compensation and market performance, for example, Masson (1971) and Coughlan and Schimdt (1985), and they exhibited statistically significant relationships between CEO compensation and better stock price performance. A few studies like for instance Westphal and Zajac (1998) concentrated on LTIPs and yielded significant positive relationship with stock market performance. This suggests that future research should focus more on the LTIP performance-pay relationship.

Finally, we also observed that for the few studies that concentrated on the relationship between LTIPs and accounting performance (for example, Cao \& O'Halloran, 2012) the findings were that the adoption of LTIPs isn't related to contemporaneous accounting performance. Most studies in this regard concentrated on the relationship between total management compensation and ROA as a prime measure of performance (see for example, Antle \& Smith, 1986; Firth et al., 2007) and their results yielded a positive association between total management compensation and ROA. Perhaps it is only Fatemi et al. (2003) in this empirical review that conducted a study on executive compensation, MVA and EVA albeit their findings are mixed in the sense that the relationship between executive compensation and MVA was significant, and the relationship between executive compensation and EVA was significantly weak. Future studies should therefore focus on LTIPs and other measures of financial performance like cash flows (free cash flows), and strategic performance measures like customer satisfaction, employee satisfaction, environmental performance and social performance, among other things.

\section{Conclusion}

Based on the results of this empirical review we conclude that studies on LTIs and corporate performance are far from being conclusive. Hence, this calls for further research into this area and particularly in the African context because only a few studies have been carried out on the relationship between LTIs and corporate performance in Africa.

\section{REFERENCES}

Aduda, J. (2011). The relationship between executive compensation and firm performance in the Kenyan banking sector. Journal of Accounting and Taxation, 3(6), 130-139.

Agarwal, A., Makhija, A.K., \& Mandelker, G.N. (1991). Executive compensation and corporate performance in electric and gas utilities. Journal of Financial Management.

Antle, R., \& Smith, A. (1986). An Empirical investigation of relative performance evaluation of corporate executives. Journal of Accounting Research, 24, 1-39.

Biagi, M., Bonner, M., Peek, L., \& Burek, M. (2015). Changing practices in executive compensation: Long-term incentive plan design. CAP Newsletter, 16.

Boivie, S., Bednar, M. K., \& Barker, S. B. (2012). Social comparison and reciprocity in director compensation. Journal of Management.

Boschen, J.F., Duru, A., Gordon, L. A., \& Smith, K. J. (2003). Accounting and stock price performance in dynamic CEO compensation arrangements. The Accounting Review, 78, 143-168.

Bolton, P., Scheinkman, J., \& Xiong, W. (2002). Pay for Short-term performance: Executive compensation in speculative markets. Journal of Corporate Law.

Bruce, A., Skovoroda, R., Fattorusso, J., \& Buck, T. (2007). Executive bonus and firm performance in the UK. Long Range Planning, 40, 280-294.

Bryson, A. Freeman, R., Lucifora, C., Pellizzari, M., \& Pérotin, V. (2012). Paying for performance: incentive pay schemes and employees' financial participation. CEP Discussion Papers, CEPDP1112. Centre for Economic Performance, London School of Economics and Political Science, London, UK.

Cao, T., \& O'Halloran, G. (2012). CEO Long-term incentive compensation plans and firm performance. International Review of Business Research Papers, 8, No.7, 1-16.

Cready, W.M., Dai, Z., \& Ma, G. (2012). Bonus rigidity and future performance: Theory and Evidence. http://ssrn.com/abstract $=2053338$. 
Cooper, M.J., Gullen, M., \& Rau, P.R. (2009). Performance for pay? The relationship between CEO incentive compensation and future stock price performance. Social Science Research Network.

Coughlan, A., \& Schmidt, R. (1985). Executive compensation, management turnover and firm performance. Journal of Accounting and Economics, 7, 43-66.

Crumley, C. (2008). A study of the relationship between firm performance and CEO compensation in the U.S. commercial banking industry. Journal of Applied Management and Entrepreneurship, 13, 26-46.

Deysel, B., \& Kruger, J. (2015). The relationship between South African CEO compensation and company performance in the banking industry. South African Business Review, 19 (1).

Fatemi, A., Desai, A.S., \& Katz, J.P. (2003). Wealth creation and managerial pay: MVA and EVA as determinants of executive compensation. Global Finance Journal, 14(2), 159-179.

Finkelstein, S., \& Boyd, B.K. (1998). How much does the CEO matter? The role of managerial discretion in the setting of CEO compensation. Academy of Management Journal, 41(2): 179199.

Firth, M., Fung, P. M. Y., \& Rui, O. M. (2007). How ownership and corporate governance influence chief executive pay in China's listed firms. Journal of Business Research, 60, 776-785.

Frans, M. (2014). Meta-theoretical framework for executive compensation. Mediterranean Journal of Social Sciences, 5(23).

Gerakos, J. J., Ittner, C. D., \& Moers, F. (2012). Compensation objectives and business unit pay strategy. Journal of accounting Research, 50 (2), 335-347.

Gomez-Mejia, L. R., Makri, M., \& Larraza K.M. (2010). Diversification decisions in family controlled firms. Journal of Management Studies, 47, 223-252.

Greckhamer, T. (2011). Cross-cultural differences in compensation level and inequality across occupations: A set-theoretic analysis. Organization Studies, 32 (1), 85-115.

Hass, L.H., Liu, J., Young, S., \& Zhang, Z.(2014). Measuring and rewarding performance: Theory and evidence in relation to executive compensation. Lancaster University Management School, Lancaster University, Lancaster: UK.

Hayes, R.M., \& Schaefer, S. (2000). CEO pay and the Lake Wobegon effect. Journal of Financial Economics, 94, 280-290.

Hrebiniak, L. G., \& Joyce, W.F. (1985). Organisational adaptation: Strategic choice and environmental determinism. Administrative Science Quarterly, 336-349.

Jensen, M.C., \& Murphy, K.J. (1990). Performance pay and top management incentives. Journal of Political Economy, 98, 2, 225-264.

Kato, T., \& Long, C. (2005). Executive compensation, firm performance, and corporate governance in China: Evidence from firms listed in the Shanghai and Shenzhen Stock Exchanges. IZA Discussion Paper No. 1767.

Kurawa, J.M., \& Saidu, S.K. (2014). Executive compensation and financial performance of listed banks in Nigeria: An empirical analysis.” Researchjournalis Journal of Accounting, 2(3), 1-13.

Maloa, F. (2014). Meta-theoretical framework for executive compensation. Mediterranean Journal of Social Sciences, 5(23).

Masson, R.T. (1971). Executive motivations, earnings, and consequent equity performance. Journal of Political Economy, 79(6), 1278-1292.

Mcknight, P. J., \& Tomkins, C. (1999). Top executive pay in the United Kingdom: A corporate governance dilemma. International Journal of the Economics of Business, 6, 223-243.

Merhebi, R., Pattenden, K., Swan, P.L., \& Zhou, X. (2006). Australian chief executive officer remuneration: Pay and performance. Accounting and Finance, 46, 481- 497.

Mnzava, B. (2012). Directors' Remuneration and its Determinants: What Do We Know? Business and Management Review, 2 (4), 42-59.

Murphy, K. J. (1985). Corporate performance and managerial remuneration: An empirical analysis. Journal of Accounting and Economics, 7, 11-42.

Nelishan, O. (2007). Do corporate governance mechanisms influence CEO compensation? An empirical investigation of UK companies. Journal of Multinational Financial Management, 17, 349-364. 
Nyberg, A.J., Pieper, J.R., \& Trevor, C.O. (2014). Pay-for-performance's effect on future employee performance: Integrating psychological and economic principles toward a contingency perspective. Journal of Management.

Scholt, H.E., \& Smith, A. (2012). Executive remuneration and company performance for South African companies listed on the Alternative Exchange (AltX). South African Business Review, 16(1).

Stabile, S.J. (1999). Motivating Executives: Does performance-based compensation positively affect managerial performance? U.A.P Journal of Labour and Employment Law, 2.2.

Sun, S.L., Zhao, X., \& Yang, H. (2010). Executive compensation in Asia: A critical review and outlook. Asia Pacific Journal of Management.

Trevor, J. (2011). Can pay be strategic?: A critical exploration of strategic pay in practice. New York: Palgrave Macmillan.

Westphal, J., \& Zajac, E. (1998). The symbolic management of stockholders: Corporate governance reforms and shareholder reactions. Administrative Science Quarterly, 43(1), 127-153.

\section{AUTHORS' BIOGRAPHY}

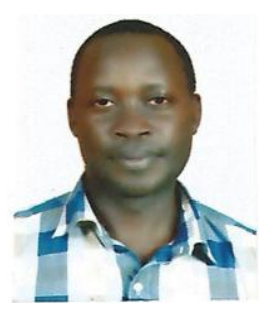

Robert Oguti Etengu is a $\mathrm{PhD}$ Accounting Candidate at Jomo Kenyatta University of Agriculture and Technology, Kenya and a Lecturer at Uganda Martyrs University.

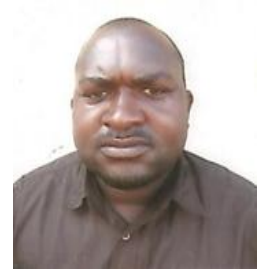

Adam Kwerigira is a former Head of Business Department and a lecturer at Islamic University in Uganda. 